\title{
Attitudes of Public and Private Schools' Students towards Learning EFL
}

\author{
Salem Saleh Khalaf Ibnian ${ }^{1, *}$ \\ ${ }^{1}$ Department of English Language and Literature, Faculty of Arts and Sciences, The World \\ Islamic Sciences and Education University, Jordan \\ *Correspondence: Department of English Language and Literature, Faculty of Arts and \\ Sciences, The World Islamic Sciences and Education University, Jordan. E-mail: \\ Salem_ibnian@yahoo.com
}

Received: December 29, 2016 Accepted: February 8, 2017 Published: June 16, 2017

doi:10.5296/ije.v9i2.8797 URL: https://doi.org/10.5296/ije.v9i2.78797

\begin{abstract}
This study aimed at exploring attitudes of public and private schools' students towards learning English as a Foreign Language (EFL) and investigating factors affecting the students' attitudes towards learning EFL.

The study attempted to answer the following questions:

1-What are the overall attitudes of public and private schools' students towards learning English as a Foreign Language (EFL)?

2- Is there a statistically significant difference between the overall mean of attitudes of public and private schools' students towards learning EFL according to the type of school (public or private)?

3- What are the main factors affecting students' attitudes towards learning EFL?

The sample of the study consisted of 144 ninth grade students chosen randomly from Amman public and private schools. The students were distributed into four sections, each section comprised 36 students.

To conduct the study, the researcher used a 20-item questionnaire to reveal attitudes of the students towards learning EFL. In addition, the researcher also carried out semi-structured interviews so as to explore factors affecting students' attitudes towards learning EFL.

Findings of the study showed that the overall mean of attitudes of public and private schools' students towards learning in EFL is positive; however, the results indicated that students of private schools have more positive attitudes towards learning EFL than students of public schools.

The findings showed that methods of teaching, the physical environment and the educational setting of schools were the main factors that affected students' attitudes towards learning EFL.
\end{abstract}

Keywords: attitudes, EFL, public and private schools 


\section{Introduction}

Attitude and motivation are considered to be key factors in language learning as they would appear to influence students' success or failure in the language acquisition. Fakeye (2010) indicated that "learners' attitudes towards the language were found to be one of the vital factors influencing foreign language acquisition".

Attitude is one of the factors that influence foreign language learning because how much effort students put into language learning depends partly on attitude (Gardner, Lanlonde and Moorcroft, 1985).

Montano and Kasprzyk (2008) described that "attitude may be determined by the individuals' thinking and ideas about behavioral beliefs and beliefs are given importance by the evaluations of the traits performed in different situations. In this way, the people who have positive beliefs about anything will definitely end up in positive attitude and positive behavior and similarly, the people with negative beliefs will consequently have negative attitude and behavior about anything".

According to Spolsky (2000), attitudes towards the language may have a positive or negative impact on the learners' fears, feelings, or prejudice for learning English as a second language. In other words, it is the learners' attitudes, skills, and strategies that determine if the learners may be able to grasp the details of language (Nunan, 2000).

As for the importance of revealing students' attitudes towards language learning, Al-Noursi (2013) said that "studying language attitudes benefits all stakeholders in different ways. Firstly, an investigation into students' attitudes is an effective method by which language teachers, education planners, syllabus designers and researchers can obtain greater understanding into the language learning/teaching process. Secondly, students have different needs, preferences, beliefs, learning styles, and educational backgrounds, and that imposition of change upon these factors can lead to negative reactions. Thirdly, learners have views on the learning process and can articulate them".

Saidat (2010) pointed out that "language attitude research has been considered in the previous 50 years because of the growing relation between the importance of the language use and the nature of individuals".

Thus, the current study comes to reveal attitudes of public and private schools' students towards learning EFL as well as to explore factors that affect the students' attitudes towards learning EFL.

\section{Statement of the Problem}

The problem addressed by this study can be stated in the different attitudes of students towards leaning EFL. Consequently, the present study attempted to answer the following questions: 
1-What are the overall attitudes of public and private schools' students towards learning EFL?

2- Is there a statistically significant difference between the overall mean of attitudes of public and private schools' students towards learning EFL according to the type of school (public or private)?

3- What are the main factors that affect students' attitudes towards learning EFL?

\section{Aims of the Study}

The current study aimed at:

- Revealing Attitudes of the public and private schools' students towards learning EFL.

- Exploring factors affecting the students' attitudes towards learning EFL.

\section{Instrument}

To carry out the study, the researcher used an attitudes scale that covered the four language skills (listening, speaking, reading and writing). In addition, the researcher conducted a number of semi-structured interviews with students from the public and private schools so as to explore factors that affected their attitudes towards learning EFL.

\section{Significance of the Study}

The current study is expected to help in revealing attitudes of the public and private schools' students towards learning EFL and highlighting factors affecting students' attitudes, a fact that is expected to be reflected positively on the educational outcomes in general, and learning EFL in particular.

\section{Limitations of the Study}

- The current study was limited to investigating attitudes of Amman public and private schools' students towards learning EFL.

- The current study was confined to exploring attitudes of the ninth grade students towards learning EFL.

- The current study was conducted in the first semester of the academic year 2016-2017.

\section{Theoretical Background and Related Studies}

The matter of learner's attitude is acknowledged as one of the most important factors that affect language learning (Fakeye, 2010). 
In foreign language learning context, there are various factors that influence the learning process such as motivation, attitudes, anxiety, learning achievements, aptitudes, intelligence, age, personalities, etc. (Shams, 2008).

Nathalie (2016) noted that learners' motivation and positive attitude during the instructional episodes is vital in ensuring that the learners persist adequately to successfully acquire the second language.

Kara (2009) pointed out that attitudes towards learning besides opinions and beliefs have an obvious influence on students' behaviors and consequently on their performance, noting that " the learning process is considered as a positive change in the individuals' personality in terms of the emotional, psychomotor (behavioral) as well as cognitive domains, since when one has learned a specific subject, he/she is supposed to think and behave in a different manner and one's beliefs have been distinguished.

Gardner (1985) pointed out that attitude is an evaluative reaction to some referent or attitude object, inferred on the basis of the individual's beliefs or opinions about the referent. "Attitude is thus linked to a person's values and beliefs and promotes or discourages the choices made in all realms of activity, whether academic or informal."

Wenden (1991) presented a comprehensive definition of the attitude concept. He classified the term "attitude" into three interrelated components namely, cognitive, affective and behavioral. The cognitive component involves the beliefs, thoughts or viewpoints about the object of the attitude. The affective component refers to the individual's feelings and emotions towards an object, whether he/she likes or dislikes. The behavioral component involves the tendency to adopt particular learning behaviors.

As attitude is one of the key predominant factors for success in language learning, numerous studies have already been conducted in the field of language attitude.

Alfauzan and Hussain (2017) investigated the attitude and perception of Saudi undergraduate students towards English literature courses as a part of their BA English Program at a large public university in KSA. A total of 59 students participated in the study.

Applying mixed method research design, questionnaires were used to collect quantitative data and retrospective essays were used for qualitative data. A modified version of AMTB developed by Gardner and associates was used to measure students' attitude towards literature courses. The results of study showed that the participants have positive attitude towards literature courses. The findings also suggested that learners' social environment (family, friends, classmates, teachers...etc.) significantly contributed in constructing positive attitudes and enhancing their perception towards literature as medium of learning L2.

Ja'ashan (2015) investigated perceptions and attitudes towards blended learning for English Courses. The sample of the study comprised (130) respondents enrolled in English department at University of Bisha in Saudi Arabia. The study concluded that the students' perceptions and attitudes towards blended learning were positive. The study also concluded 
that blended learning is as effective as face to face learning in developing and improving knowledge and skills of students.

Samadani and Ibnian (2015) investigated the relationship between Saudi EFL students' attitudes towards learning English and their academic achievement. The sample of the study comprised 112 English major students from Umm Al Qura University / Al Qunfudah branch. The result showed that there was a clear correlation between the students' GPAs and their attitudes towards learning EFL. The high GPA students showed the most positive attitudes towards learning English, followed by the medium GPA students and finally the low GPA students.

Gomez and Perez (2015) conducted a study to investigate Chilean 12th graders' attitudes towards English as a foreign language The sample of the study comprised 154 students from Puerto Montt, Chile. A questionnaire of five dimensions was given to the participants in order to identify the students' attitude towards teachers' methodology and language use in the English classroom, English as a subject at school, English as a global language, and learning EFL in Chile.

Results indicated that the students' attitudes towards English are favorable; however, the dimensions related to attitudes towards learning English and English as a subject at school obtained unfavorable responses.

Al- Noursi (2013) conducted a study to identify UAE Applied Technology High School students' attitudes towards learning the English language and to investigate whether the students' attitude is affected by the teacher's nativity. The study sample consisted of 196 students at the Applied Technology High School (ATHS). A questionnaire was used for data collection. The findings showed that the vast majority of the subjects of the study had positive attitudes towards learning the English Language. In addition, the findings revealed that teacher's nativity (native speaker vs non -native speaker of English) did not influence students' positive orientation toward the English language.

Tuncok (2010) investigated Turkish students' attitudes towards computer-assisted language learning. Findings of the study showed that most of the students have positive attitudes towards computer assisted learning, computer assisted language learning and foreign language learning.

The findings of a study by al-Tamimi and Shuib (2009) on Petroleum Engineering students' motivation and attitudes towards learning English revealed that they had positive attitudes towards the use of English in the Yemeni social and educational contexts. They also showed affirmative attitude towards the culture of the English speaking world.

Al-Zahrani (2008) conducted a study to determine the attitudes of Saudi students towards English after passing three years in learning English language. The statistical analysis revealed that there was not any clear difference among the three years in their attitudes towards Learning English as the descriptive statistics showed that the respondents in the three years had the same level of attitude. 


\section{Research Methodology and Procedures}

To conduct the study, the researcher used a questionnaire to measure students' attitudes towards learning EFL. The questionnaire was adapted from Samadani, H. and Ibnian, S.(2015).

To guarantee the validity of the questionnaire, it was submitted to a number of experts and specialists in the field of TEFL. The questionnaire was modified according to comments and suggestions.

The 20-item questionnaire comprised positive and negatives items covering the four language skills (listening, speaking, reading and writing) as follows:

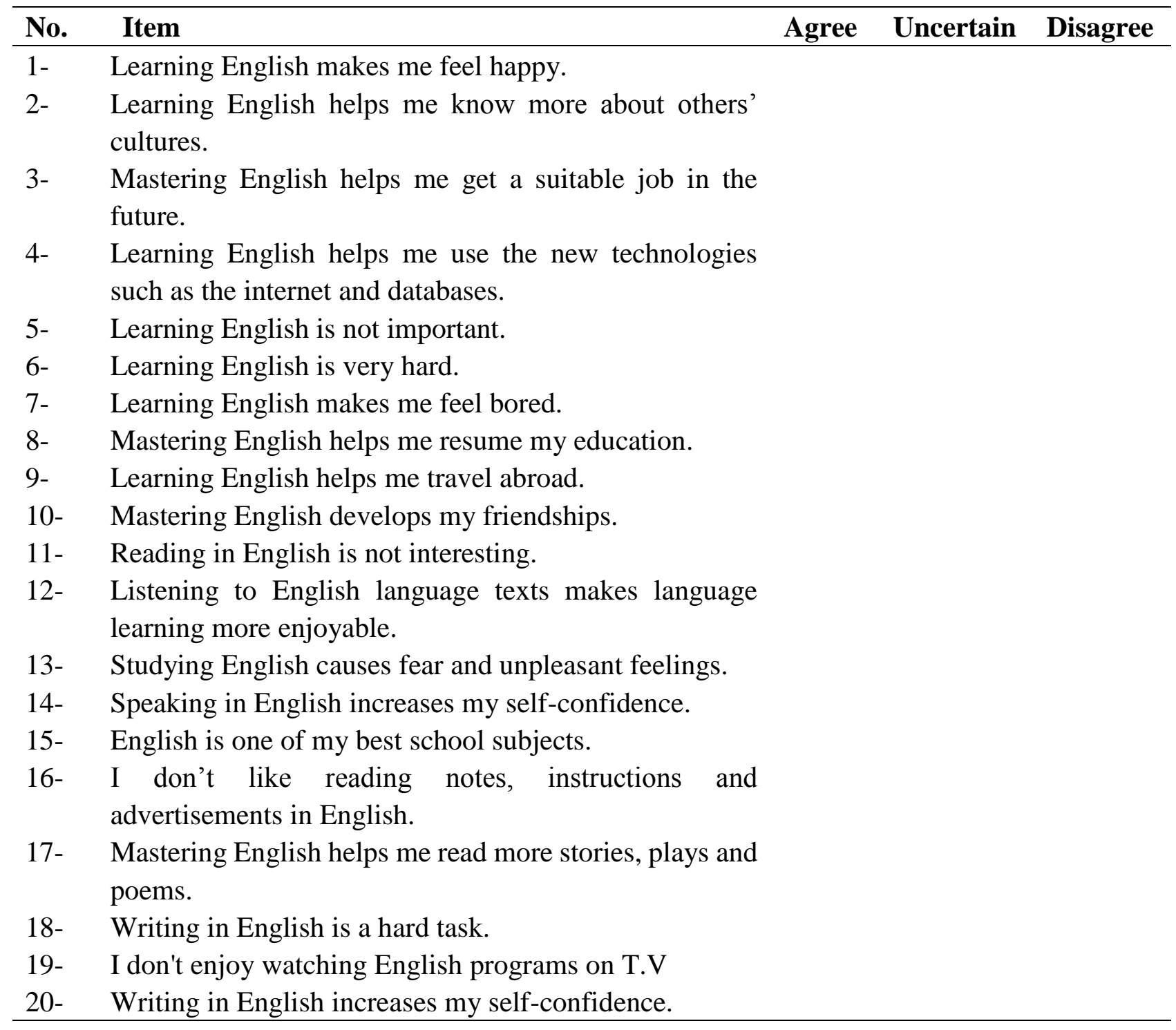

Moreover, the researcher conducted semi-structured interviews with eight students from the public and private schools so as to gain insight into factors associated with their attitude toward learning EFL. 


\section{Macrothink}

\section{Sample of the Study}

The sample of the study consisted of 144 students (four groups), chosen randomly from Amman public and private schools. Each group comprised 36 students. The participants were distributed as shown in table 1:

Table 1. Distribution of the Sample

\begin{tabular}{lll}
\hline Type of School & School & Number of students \\
\hline Public & Tareq bin Ziad School & 36 \\
Public & Tawfiq Kreishan School & 36 \\
Private & Al Hijaz School & 36 \\
Private & Al Ferdous School & 36 \\
\hline
\end{tabular}

\section{Procedures of the Study}

To answer the questions of the study, the researcher has:

1- Reviewed the related literature in the field of English language teaching and learning.

2- Reviewed the related literature in the field of attitudes towards learning EFL and designed a questionnaire to measure attitudes of students towards learning EFL.

3- Chosen the sample of the study (four groups from private and public schools).

4- Administered the attitudes questionnaire to the sample of the study.

5- Interviewed a number of students from the private and public schools so as to reveal factors affecting their attitudes towards learning EFL.

6- Collected and analyzed data.

7- Discussed results of the study.

8- Introduced conclusion and recommendations of the study.

\section{Data Analysis and Findings}

To achieve aims of the study, the researcher used two instruments, a students' questionnaire and semi-structured interviews.

A 20- item questionnaire was distributed to 148 participants (ninth graders from public and private schools). However, only 144 questionnaires were filled out and returned.

Results of the study, as shown in table (2), indicate that the overall mean of public and private schools' attitudes towards learning EFL is positive. 


\section{Macrothink}

The overall mean of attitudes of the public schools' students towards learning EFL is (2.09) with Std. Deviation (0.48), while the overall mean of attitudes of private the schools' students towards learning EFL is (2.25) with Std. Deviation (0.64).

Table 2. The overall mean and Std. deviation of public and private schools' attitudes towards learning in EFL

\begin{tabular}{llllll}
\hline School type & $\begin{array}{l}\text { Number of } \\
\text { students }\end{array}$ & Mean & $\begin{array}{l}\text { Std. } \\
\text { Deviation }\end{array}$ & T & P-value \\
\hline (Public) & $\mathbf{7 2}$ & $\mathbf{2 . 0 9}$ & $\mathbf{0 . 4 8}$ & & \\
(Private) & $\mathbf{7 2}$ & $\mathbf{2 . 2 5}$ & $\mathbf{0 . 6 4}$ & $\mathbf{2 0 6 . 7 5}$ & $\mathbf{0 . 0 0 0}$ \\
\hline
\end{tabular}

As for the difference between attitudes of the public and private schools' students towards learning EFL, the results, as shown in table (2) and figure (1), indicate that the private schools' students have more positive attitudes towards learning EFL than the public schools' students.

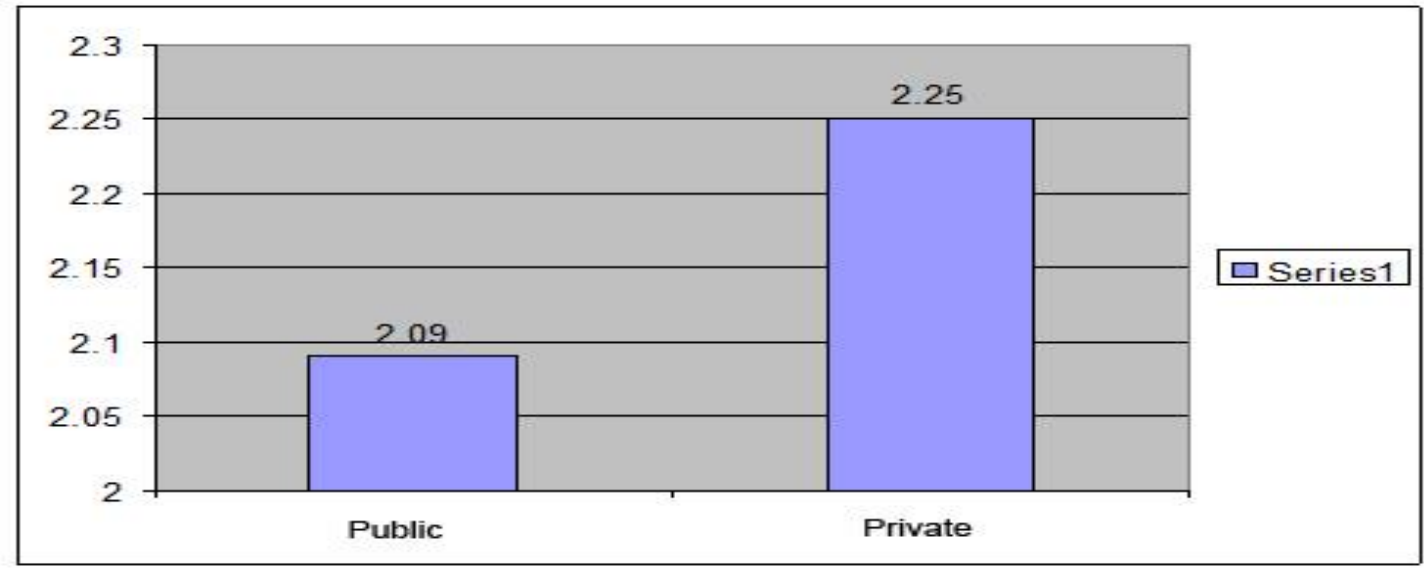

Figure 1. Mean of students' attitudes towards EFL learning according to the type of school (public and private)

Furthermore, table (3) shows mean, Std. deviation and level of each item on the attitudes scale according to responses of the public schools' students.

The table shows that items 4 and 8 ranked first jointly. Item 4 reads " learning English helps me use the new technologies such as the internet and databases", while item 8 reads "mastering English helps me resume my education". 


\section{1) Macrothink}

Table 3. Mean, Std. deviation and level of each item of the questionnaire (responses of public schools' students)

\begin{tabular}{|c|c|c|c|c|}
\hline No. & Item & Mean & Std & Level \\
\hline 4- & $\begin{array}{l}\text { Learning English helps me use the new technologies } \\
\text { such as the internet and databases. }\end{array}$ & 2.83 & 0.63 & High \\
\hline $8-$ & Mastering English helps me resume my education. & 2.83 & 0.63 & High \\
\hline $3-$ & Master English helps me get a suitable job in the future. & 2.75 & 0.77 & High \\
\hline 9- & Learning English helps me travel abroad. & 2.67 & 0.85 & High \\
\hline $2-$ & $\begin{array}{l}\text { Learning English helps me know more about others' } \\
\text { cultures. }\end{array}$ & 2.64 & 0.70 & High \\
\hline $1-$ & Learning English makes me feel happy. & 2.44 & 0.60 & High \\
\hline $14-$ & Speaking in English increases my self-confidence. & 2.42 & 0.20 & High \\
\hline $6-$ & Learning English is very hard. & 2.22 & 0.85 & Medium \\
\hline $20-$ & Writing in English increases my self -confidence. & 2.11 & 0.47 & Medium \\
\hline $10-$ & Mastering English develops my friendships. & 2.08 & 0.95 & Medium \\
\hline 7- & Learning English makes me feel bored. & 1.94 & 0.78 & Medium \\
\hline $16-$ & $\begin{array}{l}\text { I don't like reading notes, instructions and } \\
\text { advertisements in English. }\end{array}$ & 1.83 & 0.85 & Medium \\
\hline $15-$ & English is one of my best school subjects. & 1.81 & 0.22 & Medium \\
\hline $18-$ & Writing in English is a hard task. & 1.75 & 0.36 & Medium \\
\hline $13-$ & Studying English causes fear and unpleasant feelings. & 1.64 & 0.65 & Low \\
\hline 19- & I don't enjoy watching English programs on T.V. & 1.61 & 0.25 & Low \\
\hline $12-$ & $\begin{array}{l}\text { Listening to English language texts makes language } \\
\text { learning more enjoyable }\end{array}$ & 1.58 & 0.63 & Low \\
\hline $17-$ & $\begin{array}{l}\text { Mastering English helps me read more stories, plays } \\
\text { and poems in English. }\end{array}$ & 1.50 & 0.25 & Low \\
\hline $11-$ & Reading in English is not interesting. & 1.44 & 0.78 & Low \\
\hline \multirow[t]{2}{*}{ 5- } & Learning English is not important. & 1.42 & 1.10 & Low \\
\hline & Overall total & 2.09 & 0.48 & Medium \\
\hline
\end{tabular}

On the other hand, table 4 shows mean, Std. deviation and level of each item according to response of the private schools' students.

The table shows that items 8 and 9 ranked first jointly. Item 8 reads "mastering English helps me resume my education", while item 9 reads "learning English helps me travel abroad". 


\section{MInstitute Macrothink $^{m}$}

Table 4. Mean, Std. deviation and level of each item of the questionnaire (responses of private schools' students)

\begin{tabular}{|c|c|c|c|c|}
\hline No. & Item & Mean & Std & Level \\
\hline $8-$ & Mastering English helps me resume my education. & 2.94 & 0.45 & High \\
\hline 9- & Learning English helps me travel abroad. & 2.94 & 0.45 & High \\
\hline $1-$ & Learning English makes me feel happy. & 2.92 & 0.85 & High \\
\hline 4- & $\begin{array}{l}\text { Learning English helps me use the new technologies such } \\
\text { as the internet and databases. }\end{array}$ & 2.92 & 0.20 & High \\
\hline $5-$ & Learning English is not important. & 2.92 & 0.25 & High \\
\hline $2-$ & $\begin{array}{l}\text { Learning English helps me know more about others' } \\
\text { cultures. }\end{array}$ & 2.86 & 0.78 & High \\
\hline $14-$ & Speaking in English increases my self-confidence. & 2.81 & 0.96 & High \\
\hline $3-$ & $\begin{array}{l}\text { Mastering English helps me get a suitable job in the } \\
\text { future. }\end{array}$ & 2.78 & 0.58 & High \\
\hline $20-$ & Writing in English increases my self-confidence. & 2.58 & 0.33 & High \\
\hline $12-$ & $\begin{array}{l}\text { Listening to English language texts makes language } \\
\text { learning more enjoyable. }\end{array}$ & 2.53 & 0.35 & High \\
\hline $10-$ & Mastering English develops my friendships. & 2.36 & 0.35 & High \\
\hline $15-$ & English is one of my best school subjects. & 2.11 & 0.75 & Medium \\
\hline $6-$ & Learning English is very hard. & 1.89 & 0.52 & Medium \\
\hline $17-$ & $\begin{array}{l}\text { Mastering English helps me read more stories, plays and } \\
\text { poems. }\end{array}$ & 1.83 & 0.36 & Medium \\
\hline $16-$ & $\begin{array}{l}\text { I don't like reading notes, instructions and advertisements } \\
\text { in English. }\end{array}$ & 1.72 & 0.52 & Medium \\
\hline 7- & Learning English makes me feel bored. & 1.56 & 0.36 & Medium \\
\hline $13-$ & Studying English causes fear and unpleasant feelings. & 1.53 & 0.46 & Medium \\
\hline $18-$ & Writing in English is a hard task. & 1.50 & 0.36 & Medium \\
\hline $11-$ & Reading in English is not interesting. & 1.36 & 0.63 & Low \\
\hline \multirow[t]{2}{*}{$19-$} & I don't enjoy watching English programs on T.V. & 1.31 & 0.37 & Low \\
\hline & Overall mean & 2.25 & 0.64 & Medium \\
\hline
\end{tabular}

\section{Discussion}

This study examined attitudes of the of the public and private schools' students towards learning EFL. The data collected from the participants were analyzed and results were obtained. Based on findings of the study, it can be concluded that the overall attitudes of public and private schools' students towards learning EFL were positive. However, the results revealed that attitudes of the private school's students towards learning EFL were more positive than attitudes of the public school's students.

As for factors affecting the students' attitudes towards learning EFL, eight interviews were conducted with eight students from public and private schools so as to gain insight into factors associated with their attitudes toward learning EFL. 


\section{Al Macrothink}

International Journal of Education ISSN 1948-5476

2017, Vol. 9, No. 2

The semi-structured interviews showed that the instructional methods, techniques and strategies followed by teachers in the class highly affected the students' attitudes towards learning EFL. "Providing us with opportunities for working collaboratively, exchange ideas during activities and exercises highly affect our attitudes towards learning", a private school ninth grade student said.

Such results were in line with results of Yacoub (2011), which indicated that "students' success in learning a target language (TL) or a foreign language (FL) can be impacted positively or negatively by various factors, including their beliefs about how English as a Foreign Language (EFL) should be taught and their beliefs regarding characteristics of the ideal English language teacher."

Moreover, the students noted that the physical environment and the educational setting also affected their attitudes towards the learning process in general and learning EFL in particular. They indicated that the availability of language laboratory and the use of application of multimedia highly affect their attitudes towards language learning. Such results were in line with (Tuncok, 2010), which indicated that "most of the students have positive attitudes towards computer assisted learning, computer assisted language learning and foreign language learning".

In addition, the semi-structured interviews showed that the public and private schools' students were aware of the importance of English as an international language; they noted that learning English would help them explore other cultures, deal with foreigners and improve their chance of securing jobs. A public school student said: "English language is a key to open new horizons, so we have to master its skills so as to help us find jobs easily". Another private school student said: "English can help me travel abroad to explore the world and continue my education wherever I want".

These results were in line with a study conducted by Alkaff (2012), where the students said that "learning English could help them find better job opportunities, adding that English was essential for their undergraduate and post-graduate studies.

Other students pointed out to the importance of learning English in helping them deal with technological developments and communicate with new friends. "English enables me to deal with new technology and new games easily, since I can read instructions and follow them easily. It also helps me communicate with friends easily", a public school student said.

\section{Conclusion}

Based on findings of the study, it is clear that the ninth graders of public and private schools in Jordan have positive attitudes towards learning English as a foreign language (EFL), as evidenced in their responses to the questionnaire that was distributed to the sample of the study. However, students of the private sector showed more positive attitudes towards learning EFL than the public schools students. 
As for factors that affect students' attitudes towards learning EFL, the students pointed out that methods of teaching, the physical environment and the educational setting of the school highly affect their attitudes towards EFL learning.

In addition, the semi- structured interviews showed that most students believe that English is a key to success in their future life, a fact that positively affected their attitudes towards learning the foreign language.

\section{Recommendations}

Based on the findings of the study, the researcher recommends:

- Designing more technology-based activities with the aim of developing students' attitudes towards learning EFL.

- Following different strategies and techniques in the class to motivate the students and encourage them to participate effectively in English classes.

- Attaching more importance to the physical environment and the educational settings of schools, so as to contribute to developing positives attitudes towards the learning process in general and EFL learning in particular.

- Holding in-service training sessions for EFL teachers on implications of new technology in the class.

\section{References}

Al-Fauzan, A., \& Hussain, A (2017). Attitude towards and Perception of Literature in EFL Setting: A Case Study on QU Male Undergraduate Students. English Language Teaching, 10(1).

Al-Kaff, A. A. (2013). Students' Attitudes and Perceptions towards Learning English. Arab World English Journal, 4(2), 106-121.

Al-Noursi, O. (2013). Attitude towards Learning English: The case of the UAE Technological High School. Educational Research, 4(1), 21-30.

Al-Tamimi, A., \& Shuib, M. (2009). Motivation and attitudes towards learning English: A study of petroleum engineering undergraduates at Hadhramout University of Sciences and Technology. GEMA Online Journal of Language Studies, 9(2), 29-55.

Al-Zahrani, M. (2008). Saudi secondary school male students' attitudes towards English: An exploratory study. J. King Saudi University, Language and translation, 20, 25-39.

Fakeye, D. (2010). Students' Personal Variables as Correlates of Academic Achievement in English as a Second Language in Nigeria. Journal of Social Sciences, 22(3), 205-211. 
Feng. R., \& Chen, H. (2009). An analysis on the importance of motivation and strategy in postgraduates English acquisition. English Language Teaching, 2, 93-97. https://doi.org/10.5539/elt.v2n3p93

Gardner, R. (1985). Social psychology and second language learning. The role of attitudes and motivation. London: Edward Arnold.

Gardner, R.C., \& Lalonde, R.N., \& Moorcroft, R. (1985). The role of attitudes and motivation in second language learning: Correlational and experimental considerations. $\begin{array}{lll}\text { Language } \quad \text { Learning, } & \text { 207-227. }\end{array}$ https://doi.org/10.1111/j.1467-1770.1985.tb01025.x

Gomez, E., \& Pérez, S. (2015). Chilean 12th graders' attitudes towards English as a foreign language. Colomb. Appl. Linguist. J., 17(2), 313-324. https://doi.org/10.14483/udistrital.jour.calj.2015.2.a10

Ja'ashan, M. (2015). Perceptions and Attitudes towards Blended Learning for English Courses: A Case Study of Students at University of Bisha. English Language Teaching; $8(9)$.

Kara, A. (2009). The effect of a 'learning theories' unit on students' attitudes towards learning. Australian Journal of Teacher Education, 34(3), 100-113. https://doi.org/10.14221/ajte.2009v34n3.5

Montano, D. E., \& Kasprzyk, D. (2008). Theory of reasoned action, theory of planned behavior, and the integrated behavioral model. In K. Glanz, B. Rimer \& K. Viswanath (eds.), Health behavior and health education: Theory, research, and practice, 67-96. San Francisco, CA: Jossey-Bass.

Nathalie Ann C. Alaga (2016), Motivation and Attitude of Students towards Learning English Language, International Conference on Research in Social Sciences, Humanities and Education, Cebu (Philippines).

Nunan, D. (2000). Language Teaching Methodology (2nd Impression). Harlow: Pearson Education Ltd. PMCid:1221305

Saidat, A, M. (2010). Language Attitude: The Case of Jordan. International Journal of Academic Research, 2, 235-243.

Samadani, H., \& Ibnian, S (2015). the relationship between Saudi EFL students' attitudes towards learning English and their academic achievement. International Journal of Education and Social Studies, 2(1).

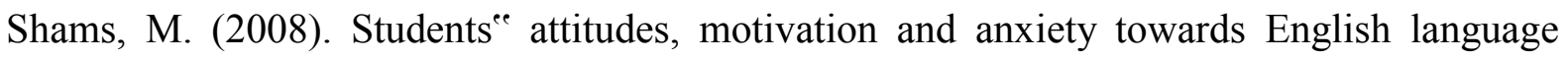
learning. Journal of Research, 2(2), 121-144.

Spolsky, B. (2000). Language motivation revisited: Anniversary article. Applied Linguistics, 20(2), 157-169. http://dx.doi.org/10.1093/applin/21.2.157

Tavil, Z. (2009). Parental Attitudes towards English Education for Kindergarten Students in 
Turkey. Kastamonu Education Journal, 17(1), 331-340.

Tunçok, B. (2010). A case study: Students' attitudes towards computer assisted learning, computer assisted language learning and foreign language learning. (Unpublished master's thesis). Middle East Technical University, Ankara.

Wenden, A. (1991). Learner Strategies for Learner Autonomy. London: Prentice Hall.

Yacoub, E. (2011). Attitudes of Jordanian Graduate Students and Teachers Towards Native and Non-Native English Language Teachers. Unpublished M.A thesis, Middle East University, Jordan.

\section{Copyright Disclaimer}

Copyright for this article is retained by the author(s), with first publication rights granted to the journal.

This is an open-access article distributed under the terms and conditions of the Creative Commons Attribution license (http://creativecommons.org/licenses/by/3.0/). 